\title{
Effect of growth regulators application on the quality maintenance of 'Brookfield' apples
}

\author{
Auri Brackmann (*); Fabio Rodrigo Thewes; Luana Ferreira dos Santos; Eduardo Perkovski Machado; \\ Vagner Ludwig; Líniker da Silva Artmann
}

Universidade Federal de Santa Maria (UFSM), Departamento de Fitotecnia, Avenida Roraima, 1.000, 97105-900 Santa Maria (RS), Brasil.

(*) Corresponding author: auribrackmann@gmail.com

Received: Feb. 6, 2015; Accepted: May 8, 2015

\begin{abstract}
The main goal of the present study was to elucidate the effect of growth regulators at harvest and postharvest quality of 'Brookfield' apples stored under controlled atmosphere through a multivariate approach. Thus, an experiment with two steps (field and storage) was carried out. The treatments in field were applied with an output of 1,000 L ha- of water. The following treatments were tested: Control: only water application; AVG (aminoethoxyvinylglycine): 0.83 kg ha-1 of Retain ${ }^{\circledR}$ applied 30 days before harvest (BH); NAA (naphthalene acetic acid): $40 \mathrm{~g} \mathrm{ha}^{-1}$ of naphthalene acetic acid applied 7 days BH; Ethephon: $2.0 \mathrm{~L} \mathrm{ha-1}$ of Ethrel ${ }^{\circledR}$ applied 10 days BH; 1-MCP: $0.625 \mu \mathrm{L} \mathrm{L-1}$ of 1-MCP (1-methylcyclopropene): applied during postharvest (storage); LE (low ethylene): with the allocation of potassium permanganate sachets during postharvest. Fruits treated with AVG in the field showed an opposite response to the fruits with NAA. AVG application followed by another growth regulator (AVG + Ethephon and AVG + NAA) showed an advance in maturation, nearing these fruits to the control treatment, this effect is likely related to the higher ethylene production by these fruits compared to fruits with AVG alone. AVG, 1-MCP and LE kept a similar response on quality maintenance. Ethephon application prevented the negative effect of NAA at harvest, but after storage, the combined $\mathrm{NAA}+$ ethephon application increased the physiological disorders, reducing internal quality.
\end{abstract}

Key words: apple, growth regulators, quality maintenance, storage.

Apples are one of the most important fruits produced worldwide. In Brazil, the apple production is concentrated in the southern States, especially in Rio Grande do Sul and Santa Catarina, with a production of 1.1 million tons per year (Informa Economcis FNP, 2012). However, this production is concentrated in a short period, from February until April, hindering the harvest. Another problem is that harvest is carried out manually and there is a shortage of manual labor. Thus, the producers use technologies that increase the harvest window and avoid losses during preharvest and postharvest.

A technology that may be used to increase the harvest window is the application of growth regulators. Some growth regulators delay harvest, preventing fruit abscission, while others seek to advance the fruit maturation therefore allowing an early harvest. NAA and AVG are applied in the field, aiming to delay harvest and fruit drop (Li \& Yuan, 2008). However, these two growth regulators decrease the red skin color development, reducing visual quality (Steffens et al., 2006). Ethephon can be applied in order to advance the ripening. The ethephon application can also neutralize the negative effect of AVG on the red skin color development of 'Gala' apples (Steffens et al., 2006), but there is a lack of studies evaluating its effect on 'Brookfield' apples. In addition to the products applied during preharvest, on postharvest other technologies are also employed, such as 1-MCP application and LE (Brackmann et al., 2014). However, there are very few studies evaluating the effect of the growth regulators application, either alone or combined, on quality at harvest and postharvest.

In this context, the main goal of the present study was to elucidate the effect of these growth regulators at harvest and postharvest quality of 'Brookfield' apples stored under controlled atmosphere through a multivariate approach.

The experiment was carried out in two steps: the first in the field in a commercial orchard located in Vacaria (RS), Brazil and the second at the Postharvest Research Center of the Federal University of Santa Maria. The plant material was composed by 'Brookfield' apples grafted on M9 rootstocks. The treatments tested were: Control: only water application; AVG: $0.83 \mathrm{~kg} \mathrm{ha}^{-1}$ of Retain ${ }^{\circledR}$ (ValentBioScience, USA, $15 \%$ of active ingredient) applied 30 days before harvest (BH); NAA: $40 \mathrm{~g} \mathrm{ha}^{-1}$ of naphthalene acetic acid applied 7 days BH (AMVAC Chemical Corporation, USA); Ethephon: $2.0 \mathrm{~L} \mathrm{ha}^{-1}$ of Ethrel ${ }^{\circledR}$ (Bayer Crop Science, Germany) applied 10 days BH; 1-MCP: $0.625 \mu \mathrm{L}$ $\mathrm{L}^{-1}$ of 1-MCP $\left(0.14 \%\right.$ active ingredient, Smartfresh $\left.{ }^{\circledR}\right)$ was applied during postharvest (storage); LE (low ethylene): with the allocation of potassium permanganate sachets 
during postharvest (Always Fresh $\left.{ }^{\circledR}\right)$. An output of 1,000L $\mathrm{ha}^{-1}$ of water was applied in the treatments carried out at the field, as proposed by Steffens et al. (2006). These growth regulators were combined and originated 10 treatments: [1] Control; [2] AVG; [3] NAA; [4] 1-MCP; [5] LE; [6] AVG + NAA; [7] AVG + Ethephon; [8] AVG + 1-MCP; [9] AVG + LE; [10] NAA + Ethephon. Each treatment was composed by 4 replicates of 25 fruits each, totalizing 100 fruits per treatment.

Immediately after harvest, the fruits were transported to the Postharvest Research Center, where a selection aiming to remove fruits with any damage due to transportation was carried out. Thereafter, a batch of fruits was analyzed before storage and another was stored under controlled atmosphere $\left(1.2 \mathrm{kPaO}_{2}+2.0 \mathrm{kPa} \mathrm{CO}_{2}\right)$ at $1.0{ }^{\circ} \mathrm{C}$ during eight months. In the storage chamber, the relative humidity was set and maintained at $94 \pm 1 \%$. In order to obtain and maintain the CA conditions fruits were put in a storage chamber with 400 liters, which allows hermetic closing. After the chamber closing, the oxygen partial pressure was reduced down to $1.2 \mathrm{kPa}$ and the dioxide carbon partial pressure was increased up to $2.0 \mathrm{kPa}$. The $\mathrm{O}_{2}$ reduction was obtained by chamber flushing with $\mathrm{N}_{2}$ down to the desired concentration. The $\mathrm{CO}_{2}$ concentration was obtained by its injection from a high-pressure cylinder that contained this gas up to the pre-established concentration. The CA condition was monitored daily throughout the storage period. The quality analysis was performed after harvest and 8 months of storage plus 7 days of shelf life at $20^{\circ} \mathrm{C}$. At harvest, the ACC oxidase enzyme activity, ethylene production, respiration rate, iodine starch, titratable acidity, soluble solids and flesh firmness were evaluated. And after storage, the internal ethylene concentration (IEC), internal carbon dioxide concentration $\left(\mathrm{ICO}_{2}\right)$, red skin color index, gas diffusion rate, mass loss, internal space, mealiness, flesh breakdown, decay incidence, healthy fruits percentage, color luminosity, intensity (Chroma) and the hue angle of skin red color were evaluated. The methodologies adopted to evaluate these parameters were: a) ACC oxidase enzyme activity ( $\mathrm{nL} \mathrm{C}_{2} \mathrm{H}_{2} \mathrm{~g}^{-1} \mathrm{~h}^{-1}$ ) evaluated according to Bufler (1986); b) ethylene production was evaluated by the stowage of approximately $1.5 \mathrm{~kg}$ of fruit inside a $5 \mathrm{~L}$ container that allow hermetically closing. The container was closed during about 2 hours and thereafter 2 aliquot of $1 \mathrm{~mL}$ were taken of and injected into a gas chromatograph model Star 3400CX (Varian, Palo Alto, CA, USA) equipped with a flame ionization detector (FID) and a Porapak N80/100 column. The temperature of injector, column and detector were 140, 90 and 200 respectively, results were expressed in $\mu \mathrm{L} \mathrm{C}_{2} \mathrm{H}_{2}$ $\mathrm{kg}^{-1} \mathrm{~h}^{-1}$; c) respiration rate: evaluated by the determination of $\mathrm{CO}_{2}$ production of the same fruits of ethylene production analysis, results expressed in $\mathrm{mL} \mathrm{CO}_{2} \mathrm{~kg}^{-1} \mathrm{~h}^{-1}$; d) titratable acidity: determined by the titration, with a $0.1 \mathrm{~N} \mathrm{NaOH}$ solution, of $10 \mathrm{~mL}$ juice diluted in $100 \mathrm{~mL}$ distillated water until $\mathrm{pH} 8.1$, results showed in meq $100 \mathrm{~mL}^{-1}$; e) iodine starch (0-10) and $\mathrm{f}$ ) soluble solids ( ${ }^{\circ}$ Brix) were evaluated according to the methodology proposed by Steffens et al. (2006); IEC $\left(\mu \mathrm{L} \mathrm{L}^{-1}\right), \mathrm{ICO}_{2}\left(\mathrm{~mL} 100 \mathrm{~mL}^{-1}\right)$, internal

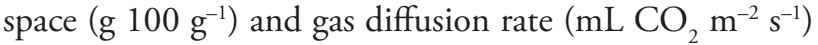
were evaluated according to the methodology proposed by Brackmann et al. (2014); red skin color index (0-3) was assessed subjectively through the identification of the skin area with red color, according to a scale of 0-3: $0=<25 \%$ of the fruit's skin was red; $1=\geq 25 \%$ up to $50 \%$ of the fruit's skin was red; $2=\geq 50 \%$ up to $75 \%$ of the fruit's skin was red; $3=\geq 75 \%$ of the fruit's skin was red. Mass loss (\%): evaluated by weighting the fruits before and after storage; mealiness (\%), flesh breakdown (\%), healthy fruits (\%), decay incidence (\%): evaluated by counting the fruits with these characteristics in relation to the total number of fruits; flesh firmness $(\mathrm{N})$ : evaluated by the insertion of an $11 \mathrm{~mm}$ tip in the two opposite sides of the equatorial region, where the skin was previously removed. The luminosity (0-100), intensity (Chroma) and hue angle of the red color were evaluated with a colorimeter (Minolta, model CR 310).

The results were submitted to a Principal Component Analysis (PCA) in order to evaluate the effect of the treatments. The data matrix was auto scaled for each variable before carrying out the PCA, in order to obtain the same weight for all variables ( mean $=0$ and variance $=1$ ).

Immediately after harvest, the fruits of the 6 treatments applied at field (Control, AVG, NAA, AVG + Ethephon, AVG + NAA and NAA + Ethephon) showed different responses in relation to the treatments (Figure 1a). Fruits that received AVG application showed an opposite response in quality maintenance compared to fruits with NAA. This result show fruits submitted to AVG application were lesser mature compared to NAA (Figure 2b). Fruits of the control treatment, AVG + Ethephon, AVG + NAA and NAA + Ethephon showed an intermediary response in relation to fruits with AVG and NAA. Brackmann et al. (2015) found a reduction in starch content, titratable acidity if the fruits were treated with ethephon and NAA after AVG application. High ethylene production and respiration rate were quantified in fruits submitted to the preharvest NAA application (Figure 1b). This result shows that fruits with NAA present a higher metabolism, resulting in higher starch degradation into soluble solids. A similar response was verified in previous studies, where NAA application increased starch degradation raising the levels of soluble solids in 'Golden Supreme' (Yuan \& Carbaugh, 2007) and 'Delicious' apples (Yuan \& Li, 2008). On the other hand, fruits treated with AVG showed higher flesh firmness and titratable acidity.

A noteworthy fact is that fruits with AVG followed by another growth regulator (AVG + Ethephon and AVG + NAA) showed an advance in maturation, nearing these fruits to the control treatment (Figure 1a). These results go against the findings proposed by Steffens et al. (2006), that no significant quality reduction was found through ethephon 
application after AVG in 'Gala' apples. On the other hand, Brackmann et al. (2014) found a significant increment in mealiness incidence by the ethephon application after AVG in 'Brookfield' apples. Another research carried out with 'Brookfield' apples found that ethephon application after AVG reduced healthy fruits amount and flesh firmness, without a significant increment in red skin color (Brackmann et al., 2015). A combined analysis of the results found in our work and the ones observed in the literature lead to a contradictory and non conclusive response, showing different effects among the cultivars studied. According to figure 1a, ethephon application after NAA reduced the negative effect of spraying NAA alone. Brackmann et al. (2014) verified a similar response in 'Brookfield' apples after long-term storage under controlled atmosphere. These authors verified a significant reduction of ethylene production, respiration rate and mealiness incidence. However, at the present research, NAA + ethephon showed a higher incidence of physiological disorders after storage than the fruits treated only with NAA (Figure 2b). This result is probably related to the transformation of ethephon into ethylene advancing the ripening of fruits and consequently physiological disorders incidence, but these fruits show a similar quality compared to control treatment fruits.

After eight months of storage plus seven days of shelf life, a principal component analysis (Figures 2a,b) was also carried out. In this analysis, the principal component one (PC I) and principal component two (PCII) represented $67.02 \%$ of the overall variation of treatments applied either before or during storage. The PCI showed that fruit with the preharvest AVG application have a different response than the control, NAA and NAA + ethephon fruits. Fruits treated with NAA + ethephon during pre-harvest showed a quality similar to the control fruits, with high mealiness incidence,
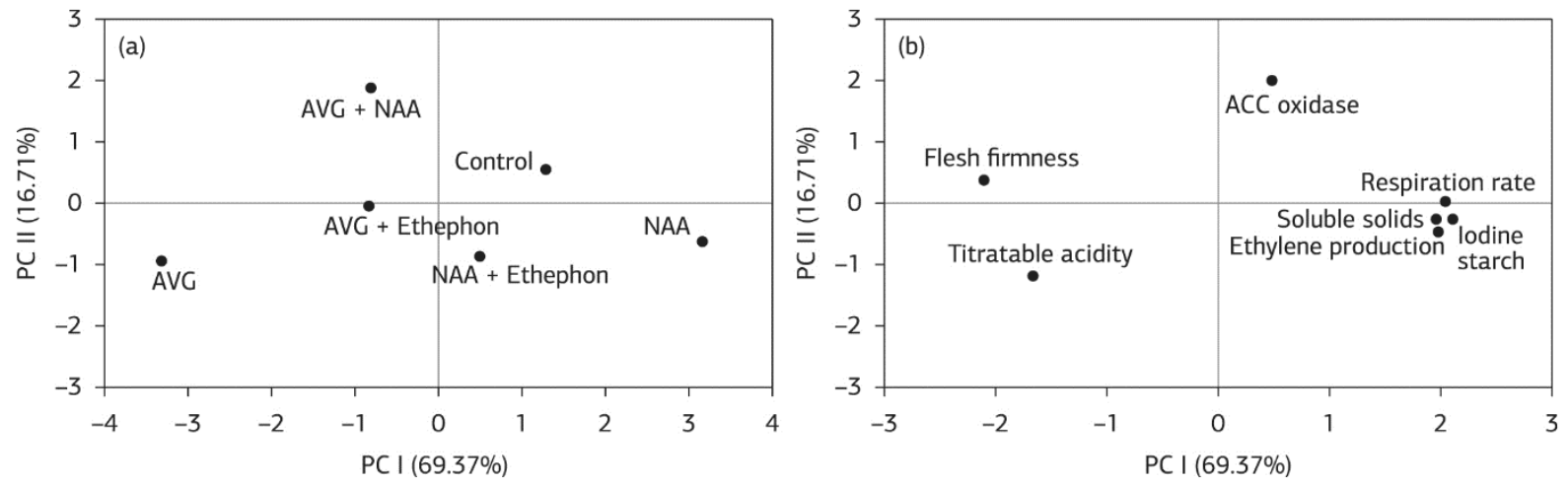

Figure 1. Principal component analysis at harvest (principal component one (PCI) and principal component two (PCII)) of 'Brookfield' apples quality, submitted to several growth regulators applied before harvest. a: shows the scores of treatments and b: shows the loadings of variables evaluated. Santa Maria, RS, Brazil, 2015. Control: Only water application before fruit harvest. AVG: aminoethoxyvinylglyce applied 30 days before harvest, by commercial product called Retain ${ }^{\circledR}$. Ethephon: Ethrel application 10 days before harvest. NAA: Auxins application 7 days before harvest.
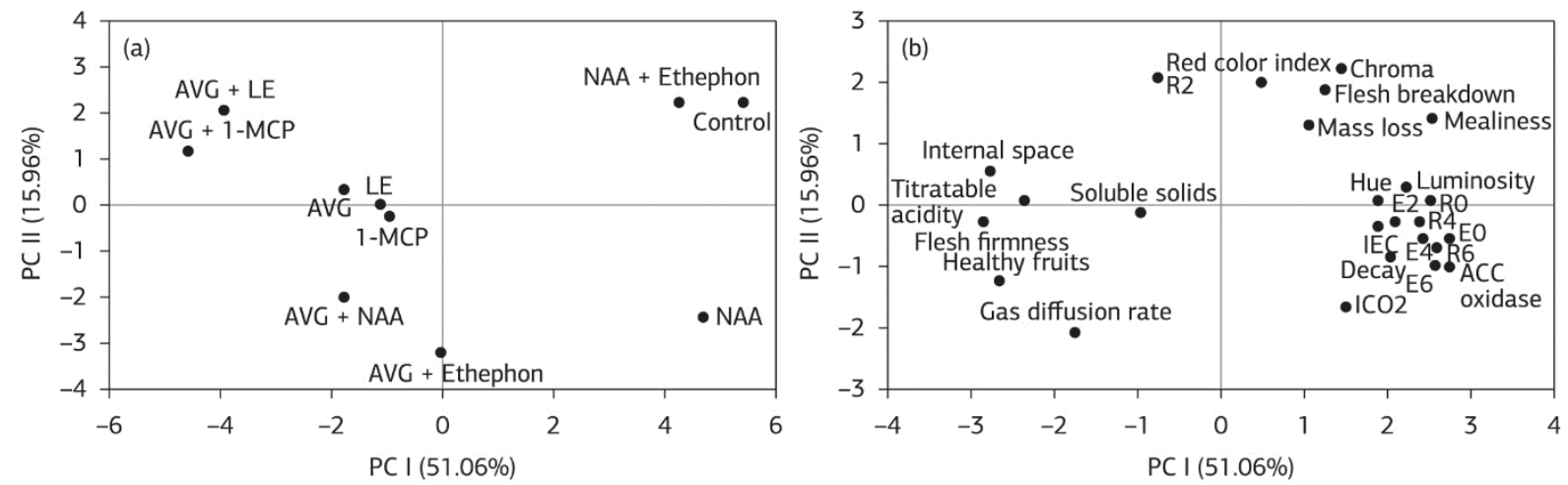

Figure 2. Principal component analysis (principal component one (PCI) and principal component two (PCII)) of 'Brookfield' apples quality, submitted to several growth regulators, applied before and after harvest, after storage under controlled atmosphere $\left(1.2 \mathrm{kPa} \mathrm{O}_{2}+2.0 \mathrm{kPa} \mathrm{CO}_{2}\right)$ during eight months plus 7 days of shelf life at $20{ }^{\circ} \mathrm{C}$. a: shows the scores of treatments and b: shows the loadings of variables evaluated. Santa Maria, RS, Brazil, 2015. Control: Only water application before fruit harvest. AVG: aminoethoxyvinylglyce applied 30 days before harvest, by commercial product called Retain ${ }^{\circledR}$. Ethephon: Ethrel application 10 days before harvest. NAA: Auxins application 7 days before harvest. 1-MCP: 1-metylcyclopropene application during postharvest life (storage), Smartfresh ${ }^{\circledR}$. LE: Ethylene absorption in chambers by potassium permanganate sachets. E0...E6: ethylene production during shelf life at $20^{\circ} \mathrm{C}$; R0...R6: respiration rate during shelf life at $20{ }^{\circ} \mathrm{C}$; IEC: internal ethylene concentration; $\mathrm{ICO}_{2}$ : internal carbon dioxide concentration. 
flesh breakdown and mass loss. Despite the physiological disorders, this is an important practical result, once we can realize the preharvest management with $\mathrm{NAA}+$ ethephon without significant quality losses during storage compared to fruits without any type of growth regulator (control fruits). The external quality of the fruits submitted to $\mathrm{NAA}+$ ethephon was high, especially regarding the high red skin color index and red color intensity (Chroma). In 'Gala' (Steffens et al., 2006; Wang \& Dilley, 2001) and 'Jonagold' apples (Wang \& Dilley, 2001), the ethephon application after AVG increased the red skin color index, lowering the negative effect of AVG on red skin color formation. However, at the present work this effect was not observed, probably due to the different cultivar. Brackmann et al. (2015) working with 'Brookfield' apples also did not find significant increment in red skin color by ethephon application after AVG application, corroborating our findings.

Fruit treated with AVG, by itself or combined with another growth regulator, showed high quality after storage (Figures 2a,b). Fruits from these treatments presented high levels of flesh firmness, internal space, gas diffusion rate, titratable acidity, soluble solids and healthy fruits. Perhaps, the low IEC, ethylene production and respiration rate in fruits treated with AVG result in lower cell wall degrading enzyme activity, once these enzymes are started by ethylene (Nishiyama et al., 2007; Payasi et al., 2009; Wei et al., 2010), leading in fruits with high flesh firmness and low physiological disorders. The high quality of these fruits is due to the lower ethylene production, respiration rate, IEC and $\mathrm{ICO}_{2}$, since great part of these variables have an inverse correlation with quality, especially physiological disorders and gas diffusion rate (Brackmann et al., 2014). Previous researches have verified the maintenance of quality through AVG application in some apple cultivars (Brackmann et al., 2014, 2015; Steffens et al., 2006; Wang \& Dilley, 2001; Yuan \& Carbaugh, 2007; Yuan \& Li, 2008).

Fruits treated with AVG, 1-MCP and LE kept a similar response regarding the maintenance of quality, however when these treatments were combined, an improvement in quality maintenance happened after long-term storage. Ethephon application prevented the negative effect of NAA at harvest, but after storage the combined NAA + ethephon application increased physiological disorders, reducing internal quality compared to NAA alone, but NAA + ethephon show similar quality to control fruits.

\section{ACKNOWLEDGEMENTS}

To Conselho Nacional de Desenvolvimento Científico e Tecnológico for financial support by granting Researcher, Doctoral and Masters Fellowships.

\section{REFERENCES}

Brackmann, A., Thewes, F. R., Anese, R. O., \& Both, V. (2014). Effect of growth regulators on 'Brookfield' apple gas diffusion and metabolism under controlled atmosphere storage. Pesquisa Agropecuaria Brasileira, 49, 323-329. http://dx.doi.org/10.1590/S0100-204X2014000500001.

Brackmann, A., Thewes, F. R., Anese, R. O., Both, V., Linke, W., Jr., \& Schultz, E. E. (2015). Aminoethoxyvinylglycine: isolated and combined with other growth regulators on quality of 'Brookfield' apples after storage. Scientia Agricola, 72, 221-228. http://dx.doi. org/10.1590/0103-9016-2014-0099.

Bufler, G. (1986). Ethylene-promoted conversion of 1-aminocyclopropane1-carboxylic Acid to ethylene in peel of apple at various stages of fruit development. Plant Physiology, 80, 539-543. http://dx.doi.org/10.1104/ pp.80.2.539. PMid:16664658.

Informa Economcis FNP (2012). Agrianual 2012: Anuário da Agricultura Brasileira. São Paulo: FNP. 497 p.

Li, J., \& Yuan, R. (2008). NAA and ethylene regulate expression of genes related to ethylene biosynthesis, perception, and cell wall degradation during fruit abscission and ripening in 'Delicious' apples. Journal of Plant Growth Regulation, 27, 283-295. http://dx.doi.org/10.1007/ s00344-008-9055-6.

Nishiyama, K., Guis, M., Rose, J. K. C., Kubo, Y., Bennett, K. A. B., Wangjin, L., Kato, K., Ushijima, K., Nakano, R., Inaba, A., Bouzayen, M., Latche, A., Pech, J. C., \& Bennett, A. B. (2007). Ethylene regulation of fruit softening and cell wall disassembly in Charentais melon. Journal of Experimental Botany, 58, 1281-1290. http://dx.doi.org/10.1093/ jxb/erl283. PMid:17308329.

Payasi, A., Mishra, N. N., Chaves, A. L. S., \& Singh, R. (2009). Biochemistry of fruit softening: an overview. Physiology and Molecular Biology of Plants, 15, 103-113. http://dx.doi.org/10.1007/s12298009-0012-z. PMid:23572919.

Steffens, C. A., Guarienti, A. J. W., Storck, L., \& Brackmann, A. (2006). Maturation of the 'Gala' apple with preharvest sprays of aminoethoxyvinylglycine and ethephon. Ciência Rural, 36, 434-440. http://dx.doi.org/10.1590/S0103-84782006000200012.

Wang, Z., \& Dilley, D. R. (2001). Aminoethoxyvinylglycine, combined with ethephon, can enhanced red color development without overripening apples. HortScience, 36, 328-331. Retrieved in November 08, 2014, from http://hortsci.ashspublications.org/content/36/2/328.full.pdf

Wei, J., Ma, F., Shi, S., Qi, X., Zhu, X., \& Yuan, J. (2010). Changes and postharvest regulation of activity and gene expression of enzymes related to cell wall degradation in ripening apple fruit. Postharvest Biology and Technology, 56, 147-154. http://dx.doi.org/10.1016/j. postharvbio.2009.12.003.

Yuan, R., \& Carbaugh, D. H. (2007). Effect of NAA, AVG, and 1-MCP on ethylene biosynthesis, preharvest fruit drop, fruit maturity, and quality of 'Golden Supreme' and 'Golden Delicious' apples. HortScience, 42, 101-105. Retrieved in November 06, 2014, from http://hortsci. ashspublications.org/content/42/1/101.full.pdf+html

Yuan, R., \& Li, J. (2008). Effect of sprayable 1-MCP, AVG, and NAA on ethylene biosynthesis, preharvest fruit drop, fruit maturity, and quality of 'Delicious' apples. HortScience, 45, 1454-1460. Retrieved in October 30, 2014, from http://hortsci.ashspublications.org/ content/43/5/1454.full.pdf+html 